\title{
Pertempuran Baru Indonesia
}

Shohibul Anshor Siregar

Ungkapan Small is Beautiful (Kecil Itu Indah) dikenal luas terutama sejak terbitnya kumpulan essai E.F.Schumacher, seorang ekonom berkebangsaan asl Jerman yang tinggal di Inggris, pada tahun 1973. Edisi lanjut esai ini diterbitkan pada tahun 1999. Kurang lebih, kumpulan esai ini adalah sebuah telaahan ekonomi yang kritis dalam mengekspresikan perlawanan akademik-ilmiah atas keraksaan dan kerakusan yang sangat dipuja. Keraksasaan dan kerakusan yang sangat dipuja itu sebetulnya sekaligus meniscayakan penindasan atas apa pun yang oleh cara pandang dan ukuran baru (modern, kapitalistik) dianggap tak sesuai, apalagi bertentangan, dengan kerangka hegemoni. Era globalisasi dianggap sesuatu yang tak terelakkan.

The Times Literary Supplement memberi peringkat teratas kepada kumpulan esai ini di antara 100 buku tentang ekonomi yang terbit setelah perang dunia kedua. Dengan sendirinya pula tak pelak membawa E.F.Schumacher sebagai seorang tokoh pemberi kritik paling berpengaruh terhadap ekonomi Barat pada masa itu. Konon E. F. Schumacher meminjam istilah Small is Beautiful dari ungkapan dan gagasan-gagasan gurunya, Leopold Kohr, seorang filsuf dan ekonom Austria, yang dalam waktu yang lama, untuk keamanan dirinya, selalu menggunakan nama samaran Hans Kohr. Hans Kohr tidak suka sama sekali hegemoni, dan dalam kapasitasnya sebagai tokoh terbaik untuk studi ekonomi nasional pada masanya, ia begitu bersemangat merekomendasikan keberadaan negara-negara kecil sekaligus menentang proyek unifikasi luas seperti Uni Eropa.

Kajian E.F.Schumacher. Theodore Roszak memberi kata pengantar untuk kumpulan esai E.F.Schumacher. Di sana ia menegaskan bahwa selama hampir dua abad sejak Adam Smith menerbitkan bukunya Wealth of Nations pada tahun 1776, para ekonom telah mengiklankan diri sebagai komunitas paling sukses dari semua ilmuwan sosial di dunia yang efek aspirasi-aspiranya dianggap bahkan telah melampaui batas-batas ideologis. Marx dan Engels tidak mendapat tempat di sini. David Ricardo dan orangorang sefaham sama sekali tidak pernah sejenak pun meragukan bahwa ekonomi memang peringkat atas di antara ilmu-ilmu, khususnya ilmu sosial.

Tahun 1969 Hadiah Nobel untuk ilmu ekonomi didirikan. Event ini memungkinkan para ekonom mengambil tempat di samping para ilmuan fisika, kimia, dan biologi. Ilmu ekonomi semakin mengembangkan diri ke arah spesifikasi matematika dan kuantifikasi statistik dengan ambisi keberhasilan pembuktian-pembuktian empiris semua hipotesis berdasarkan postulat kapitalisme. Tidak ada pemerintah dalam masyarakat industri yang tidak memiliki rekan dari Negara-negara adidaya dengan jaringan penasihat ekonomi dari lembaga-lembaga yang diciptakan untuk semakin memperkuat posisi Negara adidaya itu.

Tetapi E. F. Schumacher bukan bagian dari gaya dominan pada masanya. la antimainstream, berjuang untuk menumbangkan kemapanan ilmu ekonomi dengan mempertanyakan sampai ke dasar-dasar psikologis dan metafisik setiap asumsi yang digunakan. Selama lebih dari dua dekade, kata Theodore Roszak, E.F.Schumacher telah memberikan ide-idenya dan menenun ekonomi sambil berharap untuk dapat 
keluar dari himpitan konstelasi kepentingan dan komitmen yang jauh dari platform perdamaian dan keadilan sosial. Pekerjaan E.F.Schumacher memiliki karakater yang lahir dari tradisi bawah tanah dan kelihatannya telah membawanya pada predikat decentralist yang pada waktu itu juga terdapat sejumlah tokoh yang dapat dikategorikan sebagai juru bicara utama untuk pandangan yang sama, seperti Pangeran Kropotkin, Gustav Landauer, Tolstoy, William Morris, Gandhi, Lewis Mumford, Alex Comfort, Paul Goodman, dan Murray Bookchin.

Selanjutnya Theodore Roszak berkata "It is therefore hospitable to many forms of free enterprise and private ownership, provided always that the size of private enterprise is not so large as to divorce ownership from personal involvement, which is, of course, now the rule in most of the world's administered capitalisms. Bigness is the nemesis of anarchism, whether the bigness is that of public or private bureaucracies, because from bigness comes impersonality, insensitivity, and a lust to concentrate abstract power. Hence, Schumacher's title, Small Is Beautiful. He might just as well have said "small is free, efficient, creative, enjoyable, enduring" — for such is the anarchist faith". Keraksasaan itu adalah musuh anarkisme, karena dari sana datang impersonality, ketidakpekaan, dan nafsu untuk memusatkan kekuasaan. Small is Beautiful bisa juga bermakna "kecil gratis, efisien, kreatif, menyenangkan, abadi. Sebuah keyakinan anarkis.

E.F. Schumacher menunjukkan negara-negara miskin tergelincir, dan didorong, dalam penerapan metode produksi dan standar konsumsi yang menghancurkan kemungkinan kemandirian dan self-help. Hasilnya adalah neokolonialisme yang melahirkan keputusasaan. Tidak berhenti sampai di sana, akhirnya tidak mungkin tak dapat dirasakan bahwa sebuah potret jelas tentang etnosentrisme dan hegemoni ekonomi jelas-jelas sebagai proses penghancuran tak hanya visi hidup masyarakat negara-negara terbelakang.

Pada masa yang dikenal sebagai era perang dingin, kekuatan dominan Barat dan Timur diwakili oleh Uni Sovyet dan Amerika Serikat. Dari fakta itu Theodore Roszak memperkuat pandangan-pandangan politik E.F.Schumacher. Disebutlah misalnya sesuatu yang sedang kita alami di Indonesia saat ini. Industri menuntut keahlian canggih dan bahan halus untuk menyelesaikan produk mewah mereka yang dengan alasan itu mereka tidak akan mempekerjakan tenaga dan sumberdaya lokal. Di Ghana Volta River, proyek listrik besar dibangun dengan uang Amerika dengan bunga tinggi, dengan segenap tipu muslihat yang dianggap sah meski sangat menghisap melebihi sifat parasit. Di tempat lain kita menemukan sejumlah megaproject bergengsi seperti bendungan tinggi Aswan Mesir, dibangun oleh uang Rusia, di negara-negara miskin terjadi tragedi menjual diri untuk industri pariwisata internasional dalam mengejar simbol-simbol kekayaan dan kemajuan Barat yang sekaligus telah mengajarkan mereka untuk menganggap pasti keinginan pengadaan bandara mewah, hotel berstandar Barat, penjual souvenir, para penghibur, dan tradisi paling membanggakan mereka segera berubah menjadi karikatur mentah. Tapi orang-orang di Negara kecil itu sama sekali tidak sadar.

Bagi E.F.Schumacher upaya pemerintah harus selalu berkonsentrasi pada pembangunan berkelanjutan. Transfer teknologi ke negara-negara Dunia Ketiga tidak 
akan memecahkan masalah mendasar dari ekonomi berkelanjutan. Di sinilah filosofi Schumacher mengunggulkan "enoughness" yang sangat menghargai kebutuhan dan keterbatasan manusia, dan penggunaan teknologi yang tepat. Kesalahan pemikiran ekonomi konvensional adalah keengganan mempertimbangkan skala untuk suatu kegiatan. Itu memang bukan suatu yang layak dipertimbangkan karena semua urusan pembangunan di negera befkembang bukannya untuk rakyatnya, melainkan untuk Negara besar yang mengendalikan iramanya. Tradisionalitas dalam memegang gagasan ekstrim bahwa lebih besar lebih baik dan dipantangkannya menggunakan produksi swadaya massa rakyat adalah tragedi berketerusan. E.F.Schumacher juga dipandang sebagai salah satu ekonom pertama yang mempertanyakan secara serius kelayakan menggunakan produk nasional bruto untuk mengukur kesejahteraan manusia.

Membaca Smal is Beautiful sebetulnya tak ubahnya sedang berkaca tentang diri sendiri, yang berdasarkan pengalaman dari satu ke lain era kepemimpinan politik, kelihatannya kesadaran tentang kemandirian tidak begitu dianggap penting kendati proklamator pernah berucap tentang mutlaknya prinsip trisakti (mandiri politik, ekonomi dan budaya). Susahkah bagi sebuah Negara menjadi Negara mandiri? Perlukah menjadi Negara mandiri? Wajibkah menjadi Negara mandiri? Amankah bagi sebuah Negara menjadi Negara mandiri di tengah-tengah kekuatan ekonomi dan politik dunia? Siapa-siapa (Negara) mana saja yang akan memarahi jika sesuatu Negara tertentu berusaha sekuat tenaganya menjadi negara mandiri? Pertanyaanpertanyaan itu bisa dianggap tidak perlu dan tidak penting, karena jawabannya pun memang bisa sangat menyesatkan.

Penutup. Lonjakan jumlah hutang luar negeri Indonesia adalah sesuatu yang begitu hangat dibicarakan belakangan. Hutang itu tidak untuk sesuatu yang bertujuan untuk kepentingan salah satu di antara kedua belah pihak. Jika dikatakan Negara paling beroleh keuntungan adalah penerima, boleh saja dan dengan argumen tersendiri sudah banyak jenis penjelasan untuk itu dari pihak pemerintah. Jika disebut Negara pemberi pinjaman tak mungkin tak ingin beroleh banyak manfaat dari pemberian hutang itu, E.F.Schumacher telah menegasikan pentingnya membangun atas dasar kekuatan sendiri, karena jeratan transfer of technology saja pun sangat diwaspadai sebagai mekanisme pemupukan ketergantungan yang mematikan.

Small is Beautiful adalah kalimat perlawanan yang tegas. Di tengah kelangkaan lapangan kerja yang terus-menerus membutuhkan pengiriman tenaga kerja ke luar negeri, berita-berita tak sedap cukup mencengangkan bahwa sebagian besar hutang itu telah memprasyaratkan tenaga kerja tanpa pembatasan keahlian dari Negara pemberi pinjaman, khususnya Cina. Ini sangat pantas ditilik dari Cina, dan sangat memilukan bagi rakyat yang tak beroleh pekerjaan dan menyebabkan keputusan menjadi TKI di manca Negara dengan kemungkinan banyak resiko. Tetapi secara politik pendapat dan aspirasi yang benar bukanlah sesuatu yang harus selalu diikuti. Mudah-mudahan semua ini tidaklah tragedi.

Anthony Reid dalam Witnesses to Sumatera, A Travellers' Anthology (Oxford University Press, 1995) yang diterjemahkan menjadi Sumatera Tempo Doeloe dari Marco Polo sampai Tan Malaka menyadarkan kita bahwa bangsa Indonesia memang 
telah lama masyhur sebagai bangsa berlimpah kekayaan dan di mata orang asing, hal itu adalah alasan kuat untuk datang, merampas dan menguasai. Mereka, orang-orang asing itu, mencatat banyak hal tentang Indonesia. Mereka bisa saja menyebut pemalas, ekstrimis, barbar, dan stereotype negatif lainnya. Bahkan pemimpin Indonesia sendiri banyak yang menerima dengan lapang dada tuduhan itu dan bersikap membebek atas konstruk merendahkan itu. Pantas pulalah S.H. Alatas dalam bukunya Mitos Pribumi Malas merasa perlu membantah. la ingin pribumi sungguhsungguh merdeka. Ini memang sudah menjadi pertempuran baru.

Shohibul Anshor Siregar Naskah ini pertamakali diterbitkan oleh Harian Waspada Senin, 27 Juni 2016, hlm B7 